Please do not remove this page

RMIT

UNIVERSITY

\title{
On technology and the prospects for good practice in the human services: Donald Schön, Martin Heidegger, and the case for phronesis and praxis
}

Emslie, Michael; Watts, Robert

https://researchrepository.rmit.edu.au/esploro/outputs/9921860811301341/filesAndLinks?institution=61RMIT_INST\&index=null

Emslie, M., \& Watts, R. (2017). On technology and the prospects for good practice in the human services:

Donald Schön, Martin Heidegger, and the case for phronesis and praxis. Social Service Review, 91(2), 319-356.

https://researchrepository.rmit.edu.au/discovery/fulldisplay/alma9921860811301341/61RMIT_INST:Resea rchRepository

Document Version: Published Version

Repository homepage: https://researchrepository.rmit.edu.au

(c) The University of Chicago

Downloaded On 2023/04/26 20:07:58 +1000 
Thank you for downloading this document from the RMIT Research Repository.

The RMIT Research Repository is an open access database showcasing the research outputs of RMIT University researchers.

RMIT Research Repository: http://researchbank.rmit.edu.aul

\begin{abstract}
Citation:
Emslie, M and Watts, R 2017, 'On technology and the prospects for good practice in the human services: Donald Schön, Martin Heidegger, and the case for phronesis and praxis', Social Service Review, vol. 91, no. 2, pp. 319-356.
\end{abstract}

See this record in the RMIT Research Repository at:

https://researchbank.rmit.edu.au/view/rmit:43534

Version: Published Version

Copyright Statement:

(C) The University of Chicago

Link to Published Version:

http://www.journals.uchicago.edu/doi/full/10.1086/692117 


\title{
On Technology and the Prospects for Good Practice in the Human Services: Donald Schön, Martin Heidegger, and the Case for Phronesis and Praxis
}

\author{
MICHAEL EMSLIE
}

RMIT University

ROB WATTS

RMIT University

\begin{abstract}
Technology is fundamental to and embedded in the way practice is conceptualized and institutionalized in social service work. Many scholars assume and expect that good practices of care are achieved with the correct application of theory produced by rigorous scientific research. However, there are significant critiques of this viewpoint. We examine the work of Donald Schön and Martin Heidegger and agree with these authors' suggestions that technical rationality and modern technology are not the way to achieve good practice in the human services. At the same time, we are not convinced that the alternatives offered by Schön (artistry) and Heidegger (techne) provide what good practice requires. We draw on Aristotle's account of the intellectual virtues and make the case for phronesis and praxis as other possibilities for inspiring new kinds of social welfare practice in the twenty-first century.
\end{abstract}

\section{INTRODUCTION}

It has become almost commonplace to hear our time described in terms that draw attention to the role played by new digital technologies. The publication of articles and books with titles like "The Second Digital Revolution" (Barnatt 2001), "The Information Revolution" (Cote 2010), or the Digital Disruption (McQuivey 2013) suggests that many commentators are in furious agreement that the beginning of the twenty-first century has been marked by rapid and extensive technological disruption that is likely to, 
or that already has, occasioned social and economic change on a scale that far eclipses any antecedent. Rob Livingstone $(2015,1)$, for example, argues that while disruptive technologies are nothing new, "what is new now is the speed, extent and unpredictability of modern digital technology-induced disruption, and that this rate of change is dramatically increasing."

No less alarming, or exciting, is the proposition that the new order ushered in by the digital disruption will invert the relationship established in the past few millennia in which humans used technology as technology starts to use humans. Predictions such as the claim that many high-skilled professions will be transformed by the new digital and robotic technologies (Brooke 2012) are now being taken seriously. Indeed, Richard Susskind and David Susskind (2015) predict that in an Internet society, citizens will neither need nor want doctors, teachers, accountants, architects, clergy, consultants, or lawyers to practice in the ways they did in the twentieth century. Others claim that many human service professions will be similarly transformed by the affordances of new technologies (Watling and Rogers 2012; Reamer 2013). ${ }^{1}$

This often breathless commentary has a powerful elective affinity with some older dispositions found in many fields of professional practice. ${ }^{2}$ Technology itself has been, and continues to be, typically understood and embedded in social service work. To help the reader better understand our approach to thinking about technology, we distinguish between two dominant understandings.

\section{TECHNOLOGY AS KNOWLEDGE}

The first understanding of technology that we consider is captured by the Oxford Dictionary's primary definition of technology as "The application of scientific knowledge for practical purposes, especially in industry.”3 This conception treats technology as knowledge and, in the human services, involves a technical-rational understanding of knowledge evident in the constitutive assumption that good practice is achieved by the cor-

1. A sober assessment of the likely influence of digital automation is provided by Adam Corlett (2016).

2. The idea of elective affinity, following Max Weber, points to a set of important correspondences between social phenomena that are not in any strict sense causal.

3. See http://www.oxforddictionaries.com/definition/english/technology. 
rect application of theory produced by rigorous scientific research. This understanding typically relies on a positivist framing of knowledge and assumes, for example, that the social world, and more particularly the problems that social welfare deals with, can be known and responded to by knowledge of entities and processes that are empirically accessible, are regular, and behave in law-like or probabilistic ways. This conception of knowledge has had a significant influence on how social services are conceptualized and realized. This conception informs evidence-based practice, the field of knowledge utilization, and implementation science (Campbell Collaboration n.d.; Early Intervention Foundation n.d.; Reamer 1993; Osmond and O'Connor 2006; Michie, Stralen, and West 2011; Gambrill 2013; Cochrane Collaboration 2015; Heinsch, Gray, and Sharland 2016). Perhaps this idea of technology as knowledge is most typically manifested in many kinds of caring work as the reliance on professional practice manuals, assessment tools, or instruments, including psychometric tests, intervention handbooks, best practice frameworks, client data management systems, and outcomes measurement guides.

\section{TECHNOLOGY AS TOOL}

The second understanding of technology that we consider, running in parallel with the representation of technology as knowledge, is the idea of technology as a tool that involves both hardware and software. ${ }^{4}$ The idea of technology as a tool is evident in such practice innovations as distance, telephone, online, and video counseling; digitalized medical diagnostics; avatar therapy; case management software; advances in assistive, adaptive, and rehabilitative technologies; and the use of information and communications technology in social service education, medical practice, and training (Kincaid 2004; Martin and Hawkins 2010; Perron et al. 2010; Reamer 2012, 2015; Berzin, Singer, and Chan 2015). Judith Bessant (2003, 2004) provides another example of technology embedded in human service practice, pointing to the role played by risk technologies. According to Bessant, scientifically produced instruments, techniques, tools, and procedures are

4. In this respect, the distinction drawn between technology as knowledge and technology as a tool is permeable. Some of the instruments that could be categorized as technology as knowledge, like psychometric tests, are easily programmed into computerized form as apps, and so they also become technology as tools. 
used extensively to identify who is at risk and to assess the type and level of risk, all with a view to determining the sort of risk management or intervention required (see also Dean 2010). This has proved irresistible to those promoting a preventive justice agenda.

These dispositions probably explain contemporary advocacy both for what is called evidence-based policy and practice and for the adoption of digital technology in various kinds of human service work (ReachOut.com n.d.; Australian Government Department of Human Services 2015; eheadspace 2015). Lesley Chenoweth and Donna McAuliffe (2012, 260-62) argue that "advances in technology affect human service practice," and their discussion focuses on technology as a tool used in practice with a particular emphasis on telecommunications and information technology. This advocacy assumes the potential of technology to variously solve problems, improve the lives of human beings, save money, and deliver efficient and highquality services (ARACY n.d.; CSIRO n.d.; Slavin and Schoech 1999; Young and Well Cooperative Research Centre 2013). While we are dealing with both technology as knowledge and technology as a tool, we are interested in the kinds of intellectual and ethical assumptions people make when they think about or use a technological frame of reference.

As Steve Matthewman notes, although "ubiquity creates invisibility," we can ill afford to be complacent about the actual value of digital technology simply because "we do not notice the obvious" (Matthewman 2011, 173). Neil Selwyn, writing about the influence of digital technology on education, is even more pointed when he argues that we need a more critical, even political, framework when thinking about new technology. He warns that too many professionals working in education simply assume, without good reasons or compelling evidence, that new technology will be benevolent or will promote efficiency, choice, and diversity (Selwyn 2014). Selwyn treats this as one consequence of an evangelical movement of advocates promoting the benefits of the new technology (Selwyn 2014).

We are inclined to agree with Matthewman (2011) and Selwyn (2014). Apart from some good reasons to worry about the claimed benefits of the new technology, this advocacy for a digital fix seems, among other failures, to conspicuously ignore or overlook the ongoing crisis that has been affecting many human service professions over the past few decades. This crisis includes a loss of trust and faith in the profession and the failure of the professions to solve critical problems (Schön 1983; Schwartz and Sharpe 2011). That crisis is an entirely appropriate context for thinking both about 
what has happened to professional practice to occasion that sense of crisis and the likelihood that the new technology will automatically contribute to an outbreak of good practice. We believe that social service professionals need to think more carefully about what we mean by good practice.

In 2011, Barry Schwartz and Ken Sharpe wrote an acclaimed critique of modern professions, including medicine, law, social welfare, and education, in America. They point to evidence that Americans in general, and people relying on medical, social welfare, legal, or education professionals in particular, were not happy. In America, a 2012 Gallup poll reported that only 29 percent of Americans had a "great deal" or "quite a lot" of confidence in public schools. This was half the confidence level reported (58 percent) in 1973 when Gallup first asked the question about public schools. They point to teachers who want "to teach kids the basics" and excite them about the prospect of educating themselves but who "feel helpless faced with the challenge of reconciling these goals with mandates to meet targets on standardized tests, to adopt specific teaching techniques, and to keep up with the ever increasing paperwork. No one is satisfied - not the professionals and not their clients" (Sharpe and Schwartz 2011, 3). Through the first decade of the twenty-first century, Gallup polls also found that 72 percent of Americans were dissatisfied with the availability of affordable healthcare, while 50 percent were dissatisfied with the quality of medical care. In Britain, only 43 percent were satisfied with their access to affordable healthcare, and only 42 percent were satisfied with the quality of that care.

This general point about a loss of confidence or faith in modern professions needs a lot more careful discussion of much more evidence than we can present here. However, we do engage with the question of why people would put so much trust or faith in a mix of technical rationality and/or in technological solutions. We treat people's faith in technical rationality and technology as two closely related themes suggested by history since the eighteenth century and the Age of Reason (or the Enlightenment) first set loose the idea that humanity was now surging into the future on a tide of progress powered by (modern) science and technology (Henry 2008). This idea and a telos (or purpose) of progress have been tirelessly promoted by early advocates like Marquis de Condorcet and Auguste Comte, as well as by more recent advocates for globalization. The idea that progress is powered by technology has also been shadowed by mordant critics like Theodor $\mathrm{W}$. Adorno, Max Horkheimer, and, more recently, John Gray. Here, we focus on the ideas of a surprising pair of critics of technology: Martin Heidegger 
(1977) and Donald Schön $(1983,1987)$. Each has made an important contribution to how we might think about the way in which we rely on both complacent representation of technology (Heidegger) and a conception of scientific knowledge (Schön). Each helps us begin to think about what good practice might look like for social welfare professionals.

In this article, we address several questions. Was Schön right to point to a problem with a technical rational model of theory and professional practice? What does Heidegger's account of technology imply about good practice, especially practice based on the premise that a technological solution is available? We explore the idea that technology has a role to play in achieving good practice in human services and examine whether technology is the answer to the puzzle of realizing good practice in human service professions.

\section{DONALD SCHÖN: THE CRISIS OF PROFESSIONAL PRACTICE}

In 1983, Donald Schön, a philosopher and professor of urban planning at the Massachusetts Institute of Technology, published one of the most widely admired books on professional practice in the twentieth century: The Reflective Practitioner: How Professionals Think in Action. ${ }^{5}$ Schön (1983) is interested in how to achieve good professional practice, and this includes examining the kinds of knowledge best suited to inform good practice. In particular, Schön explores the relationship between knowing and doing, research and practice, and thinking and acting. Schön's book is about how professional lawyers, teachers, doctors, social workers, and urban designers think about and try to link their practice and theory. Schön argues that there is strong evidence of a conspicuous and widespread failure on the part of these professions to live up to their stated ethical values, to meet the expectations of their communities, and to solve major social problems like poverty, illness, injustice, and dysfunctional cities. He claims that this failure was evident even in the 1960s and 1970s.

Schön attributes this failure to the way in which many professionals treat theory as a technical form of knowledge based in pure science, which they then use to guide their practice. In effect, he is saying that too many

5. Others have elaborated on Schön's (1983) critique (see, e.g., Grundy 1987; Dunne 1997, 2005; Thompson 2000; Flyvbjerg 2001; Eisner 2002; Carr 2004; Polkinghorne 2004; Hamilton 2005; Schwandt 2005; Kemmis and Smith 2008; Bondi et al. 2011). 
professionals believe they just need a kind of recipe, rather like a set of instructions for building an electronic device or for using a child's Lego set to build a spaceship or train. We think Schön's argument is worthy of further exploration in part because he opens up discussion about what we mean when we talk about theory and practice. ${ }^{6}$

According to Schön, most professions have a story about how their theory and practice work that is reliant on what he calls technical rationality. Schön (1983, 21) argues: "According to the model of Technical Rationality - the view of professional knowledge which has most powerfully shaped both our thinking about the professions and the institutional relations of research, education, and practice - professional activity consists in instrumental problem solving made rigorous by the application of scientific theory and technique.” The technical rational model suggests that good professional practice relies on practitioners exclusively and correctly using knowledge produced by scientific research to achieve predetermined and agreed-upon ends. According to Schön (1983, 3-4), “Technical rationality holds that practitioners are instrumental problem solvers who select technical means best suited to particular purposes. Rigorous professional practitioners solve well-formed instrumental problems by applying theory and technique derived from systematic, preferably scientific knowledge."

Schön argues that too many modern professionals treat theory as a body of clearly bounded, scientific, specialized, and standardized knowledge. This conception of theory relies on what has conventionally been referred to as the positivist conception of knowledge. This is an idea that evolved in the early nineteenth century, and it insists that the only way to say we know the truth of anything is if we have measured it and, preferably, subjected it to some kind of experimental procedure. Under positivism, anything that looks like it has to do with religion, feelings, or ethical ideas should be counted out as not being scientific. For positivists since Comte (who coined the term), the only true knowledge is grounded in a scientific experimental method. As Schön $(1983,31)$ puts it, "Technical rationality is the heritage of Positivism."

The three principal doctrines of positivism that were first outlined by Comte help us to understand technical rationality's reach and influence.

6. It is important to note that the words theory and practice are often used and misused with an almost callous disregard for the confusion set loose, because those using these words cannot, or refuse to be, clear about what these words mean. 
First, there is the conviction that empirical science is not just a form of knowledge but is the only source of positive knowledge of the world. Second, there is the intention to cleanse people's minds of mysticism, superstition, and other forms of pseudo-knowledge. Finally, there is the program of extending scientific knowledge and technical control to human society, to make technology, as Comte said, "no longer exclusively geometrical, mechanical or chemical, but also and primarily political and moral" (Schön 1983, 32).

The scientific method, when properly applied, avoids making religious, ethical, or emotional assumptions because proper science is grounded in empirical observation and rigorous mathematical testing in order to produce objective, timeless, invariant, and universal laws (Holton 1988). Theoretical knowledge is, accordingly, best expressed as laws that ideally use equations and mathematical formulations, and it is successful when an explanation also works as a prediction written out as a theorem (Schön 1983). Whether it is either possible or desirable that we generate this kind of theory in the human sciences is another matter altogether. Yet, what some call "physics envy" has proved highly seductive.

As Schön goes on to explain, professional doctors, teachers, psychologists, town planners, and social workers claim to draw on a body of theory to develop more applied versions of that theory. This requires developing day-to-day diagnostic procedures and problem-solving techniques crafted into skill-based practices and accompanied by appropriate attitudes (like the doctor's "bedside manner") and professional values like altruism. According to this point of view, professional practice is a second-order activity subordinate to theory. It follows that the more basic and fundamental the scientific theory, the higher the status of the profession relying on that science.

As Schön points out, this model of professionalism was already facing major problems by the 1980s. First, positivism itself had already fallen into disfavor among twentieth-century scientists and mathematicians in the revolution led by Albert Einstein, Werner Heisenberg, and Kurt Godel. That revolution, which included the theory of relativism and quantum physics, suggested that some core features of the universe could not be explained by the kind of classic scientific methods favored by positivism and that contemporary science needed to accept a degree of uncertainty (Heisenberg) and even mathematical undecidability (Godel). This view was recognized by Karl Popper (1979) and Thomas Kuhn (2012) and has recently been described by Marcus du Sautoy (2016). 
Second, by the 1960s and 1970s, many key professions were experiencing a crisis of legitimacy. For Schön, the central problem is the assumption, made by too many professionals relying on the technical rational model as a self-portrait, that the problems they address are technical problems. As Schön puts it, “Technical rationality depends on agreement about ends. When ends are fixed and clear then the decision to act can present itself as an instrumental problem" (Schön 1983, 41).

But what if the problems being dealt with by professionals were neither fixed nor clear? Worse, what if the problems being dealt with by professionals involved a complex set of ethical, emotional, aesthetic, or political judgments? This might go to a standard problem facing any doctor who has a patient facing death who he or she can technically save but who would be left in lifelong pain and suffering. Or, it might involve a planning decision that half of a small community wants but the other half loathes: how does a planner resolve such a problem?

As Schön argues, real professionals in every field need to make complex judgments that acknowledge the fact that they are working in communities divided by economic, gendered, religious, and ethnic interests, differences, and inequalities. This implies that even working out the nature of the problem often relies on a mix of technical and nontechnical and nonrational abilities. This recognition led Schön to propose that professional practice be redefined as reflective practice.

One further observation is warranted. Schön's account of the dominance of technical rationality in professional practice is as relevant today as it was when it was published more than 30 years ago, if not more so. The research, education, and practice of professional activities continue to resemble the model of technical rationality that Schön describes. If anything, there has been an intensification of research, education, and practice modeled on technical rationality since Schön wrote his seminal work. This has corresponded with the institutional reign of neoliberalism and New Public Management, which have become the dominant political, economic, and policy framework for many liberal welfare states like Britain, the United States, Australia, and New Zealand since the 1970s (Esping-Andersen 1990; Bessant, Farthing and Watts 2017). And, unsurprisingly, neoliberalism and New Public Management are interdependent with technical rationality, a link acknowledged extensively in the literature (Bessant 2004; Miller and Rose 2008; Dean 2010). One way this can be observed is through the sort of research that is valorized and respected by governments and 
policy makers. Research aligned with the model of technical rationality, like the evidence-based practice movement, claims to provide the knowledge and theory (through robust and rigorous research methods that are claimed to be able to precisely and unambiguously know, measure, explain, and predict) that is needed for the cost-efficient, value-for-money, auditable, and accountable service provision demanded by neoliberalism and New Public Management (see, e.g., Power 1997; Furedi 2011). We should also remember that the potential of technology was central to socialist and communist projects. It appears that technology has been critical to diverse and disparate social, economic, and political systems.

\section{THE SOLUTION ACCORDING TO SCHÖN: ARTISTRY}

\section{AND REFLECTIVE PRACTICE}

While Schön $(1983,1987)$ highlights some of the problems with a technicalrational model of theory and professional practice, he also observes that the sort of knowledge that many practitioners actually use for good professional practice has not been clearly articulated. According to Schön (1983, 1987), technical rationality is not the way of knowing that is needed for good practice, and practitioners who do not practice according to its logic are unable to talk about the knowledge they actually use in their practice, which is characterized by "complexity, uncertainty, instability, uniqueness, and value conflict” (Schön 1983, 39). Schön (1983, 19-20) argues:

Professionals have been disturbed to find that they cannot account for processes they have come to see as central to professional competence. It is difficult for them to imagine how to describe and teach what might be meant by making sense of uncertainty, performing artistically, setting problems, and choosing among competing professional paradigms, when these processes seem mysterious in light of the prevailing model of professional knowledge. We are bound to an epistemology of practice which leaves us at a loss to explain, or even describe, the competences to which we now give overriding importance.

In light of his critique of professional practice modeled on technical rationality, Schön (1983) argues for the value of an inquiry into the epistemology of practice. According to Schön (1983), this would involve asking questions like, "What is the kind of knowing in which competent practi- 
tioners engage?" and "How is professional knowing like and unlike the kinds of knowledge presented in academic textbooks, scientific papers, and learned journals?” (Schön 1983, viii). Schön undertakes a phenomenology of professional practice to learn about the epistemology of practice. This involves asking "what we can learn from a careful examination of artistry, that is, the competence by which practitioners actually handle indeterminate zones of practice" (Schön 1987, 13).

Schön makes the case for an epistemology of practice based on the idea of artistry, which he characterizes as "an exercise of intelligence" and "a kind of knowing" that involves "an art of problem framing, an art of implementation, and an art of improvisation - all necessary to mediate the use in practice of applied science and technique" (Schön 1987, 13). Schön seems to be treating the kind of knowing professionals use as a kind of art best distinguished from the model of theory that the technical-rational model of professional practice relies upon.

According to Schön $(1983,62)$, reflection in action is central to "the art through which practitioners sometimes cope with the troublesome 'divergent' situations of practice.” In other words, Schön argues that a key aspect of good practice is artistry, or performing artistically, in "the indeterminate zones of practice - uncertainty, uniqueness, and value-conflicts - [that] escape the canons of technical rationality" (Schön 1987, 6). And such artful practice involves reflection in action, or reflective practice. According to Schön (1983, 68-69), when a practitioner is performing artistically and engaging in reflective practice, he or she becomes "a researcher in the practice context" and constructs "a new theory of each unique case." This involves practitioners allowing themselves to experience surprise, puzzlement, or confusion in the practice situations that they find uncertain or unique, reflecting on the phenomena before them and carrying out an experiment that serves to generate both a new understanding of the phenomena and a change in the situation (Schön 1983).

The real value of Schön's $(1983,1987)$ work is his focus on spelling out the sort of knowledge people use in professional practice. Schön makes the case that good professional practice requires artistry and the nurturing of artistry in the education and the institutionalization of practice. And he particularly makes the case for the reflective practicum in professional education for this purpose (Schön 1987).

Although Schön's account of reflective practice still has lessons for us today, Schön is not always as clear as he might have been in saying how 
this reflection might best take place and, more importantly, why reflective practice is worth pursuing. Schön's solution of a turn to practice is not grounded in any clear or defensible critical, political, or ethical ideas or commitments. He fails to spell out the kinds of ethical ideas that might matter in defining the point and purpose of any professional practice. Schön is reluctant to detail the kinds of ethical thinking that might make reflective practice a good idea. In this respect, and by implication, we need some better fleshed-out accounts of the kinds of human goods that professional practice is oriented to achieving or promoting. ${ }^{7}$ Almost as problematic, though much less important, is that when Schön describes reflective practice, he draws on a narrow slice of professional practice: all of his examples come from American universities or colleges. Although this sounds like very harsh criticism, in effect Schön unwittingly contributes a little to the mess in which we now find ourselves by virtue of his unwillingness to provide examples of the kinds of value rationality that would address the untenable claim to value neutrality made by those advocating for a technical rational model of professional practice.

\section{MARTIN HEIDEGGER: THE DANGERS}

\section{OF A TECHOLOGICAL FIX}

Let us turn then to the German twentieth-century philosopher Martin Heidegger, who is easily one of the towering and most controversial figures in Western philosophy and someone who is not conventionally identified as having made a contribution to ethical philosophy. ${ }^{8}$ Heidegger is critical of modern technology. Can he illuminate the kinds of ethical, political, and critical ideas and commitments that might go a long way to defining and realizing good professional practice? Let us start by outlining his radical challenge to the way we know technology.

7. This clearly points to a set of interconnected problems to do with (i) how we might begin to develop such a framework based on a defensible conception of human goods, (ii) what those human goods might look like, and (iii) whether there are any guides to this in the various traditions that make up the history of practical reasoning.

8. The controversy about Heidegger goes to the question of how much his philosophy enabled his notorious embrace of Nazism in 1933-35 (see Wolin 1993; Safranski 1998). The question of Heidegger's ethical position is controversial for different reasons (see Webb 2011; Artemenko 2016) 
Unlike Schön, Heidegger does not directly examine good professional practice. However, just as Schön has a lot to say about scientific knowledge, Heidegger has a lot to say about technology. In particular, Heidegger is interested in exploring the essence of modern technology and its implications for human beings. But what does Heidegger mean by the essence of modern technology? And what are the problems of the essence of modern technology for people? And are the essence of modern technology and its associated problems evident in the practices of the helping professions? We will address each of these questions in turn to make the case that Heidegger's critique of modern technology is relevant for thinking about the prospects of human service practice embracing modern technology.

\section{THE ESSENCE OF TECHNOLOGY ACCORDING TO HEIDEGGER}

Heidegger (1977) argues that the conventional ways in which technology has been understood are correct. However, he believes that they do not capture the truth or essence of technology. In particular, Heidegger argues that treating technology as a means to an end and as a human activity, which he calls the instrumental and anthropological definition of technology, is "in principle untenable" because it diverts attention from considering its essence (Heidegger 1977, 21, 32). Heidegger (1977) argues that the essence of technology is a mode of revealing, or a realm of truth, or a way of understanding or unconcealing, or a "destining" that works to reveal. Heidegger stresses this point when he suggests, "The possibility of all productive manufacturing ...," and this includes the possibility of all ends and means or instrumentality, and the possibility of all making and manipulating, "lies in revealing" (Heidegger 1977, 12-13).9

Heidegger (1977, 14-24) argues that the mode of revealing that rules in modern technology, compared to the mode of revealing that ruled in the Middle Ages and Antiquity, is a challenging or ordering revealing, which he calls enframing. Heidegger (1977, 16-24) characterizes enframing as a revealing of nature, the world, objects, being, and "the real" that "has the

9. Heidegger's distinctive recovery and radical revision of Western approaches to truth in which he recovers and appropriates the ancient Greek idea of truth and its relationship to the concept aletheia (often translated and interpreted as unconcealment, disclosedness, revealing) is examined by Suvak (2000), Sheehan (2011), Malpas (2014), and Nicholson (2014a, 2014b). 
character of a setting-upon," or the character of an "ordering," and, in particular, a challenging, setting upon, and ordering of the real as "standingreserve." "The revealing that rules in modern technology is a challenging, which puts to nature the unreasonable demand that it supply energy that can be extracted and stored as such" (Heidegger [1922/1923] 2007, 14). As a standing reserve, the real is at people's command as the disclosers of the real as a standing reserve. In other words, the real is on call as resource or potential that is ready to be unlocked and to deliver what people demand of it. As Heidegger $(1977,17,23)$ explains, "Everywhere everything is ordered to stand by, to be immediately at hand, indeed to stand there just so it may be on call for a further ordering. Whatever is ordered about in this way has its own standing. We call it the standing-reserve. . . Enframing . . . is the way in which the real reveals itself as standing-reserve.” For Heidegger, the essence of modern technology is its power to reveal, and in particular to challenge or order, the real as calculable, orderable, and expected and ready to provide whatever people require of it.

\section{THE PROBLEMS OF ENFRAMING}

Heidegger argues that enframing poses two dangers for people. The first is that "Enframing endangers man in his relationship to himself and to everything that is" (Heidegger 1977, 27). Heidegger is particularly concerned about the ways in which enframing reveals a reduced scope to, and a specifically amplified way of, being, including human being. More to the point, Heidegger suggests that by enframing people end up conceiving of themselves and of other people as a standing reserve. And Heidegger adds that people do not realize that they are being revealed as resource or potential to be optimized and exploited. Heidegger $(1977,27)$ argues: "Man stands so decisively in attendance on the challenging-forth of Enframing that he does not apprehend Enframing as a claim, that he fails to see himself as the one being spoken to, and hence also fails in every way to hear in what respects he ek-sists, from out of his essence, in the realm of an exhortation or address, and thus can never encounter only himself."

According to Heidegger (1977, 27), the second danger of enframing is that "it drives out every other possibility of revealing." Put another way, where enframing holds sway, every other possible mode of revealing is concealed (Heidegger 1977). Heidegger argues that every mode of revealing involves concealing, and therefore every mode of revealing poses dan- 
gers. At the same time, Heidegger $(1977,26)$ emphasizes the "supreme danger" of enframing, which he argues rules when it comes to modern technology.

What is dangerous is not technology. . . . The essence of technology . . . is the danger. . . The threat to man does not come in the first instance from the potentially lethal machines and apparatus of technology. The actual threat has already affected man in his essence. The rule of Enframing threatens man with the possibility that it could be denied to him to enter into a more original revealing and hence to experience the call of a more primal truth. (Heidegger 1977, 28)

Dreyfus $(1993,305)$ stresses the point: "Heidegger's concern is the human distress caused by the technological understanding of being, rather than the destruction caused by specific technologies. . . . The threat is not a problem for which we must find a solution, but an ontological condition that requires a transformation of our understanding of being" (italics in original).

One important question we must consider is whether Heidegger's arguments about the essence of technology and its dangers, which were delivered as lectures over 65 years ago and first published soon after, are still relevant today. Don Ihde (2010), for example, questions Heidegger's relevance in light of the transition from an industrial to a post-industrial epoch. Ihde $(2010,21)$ is also critical of Heidegger's "essentialism," or subsuming all technology under the same analysis that "keeps one from seeing particularities of technologies." Heidegger wrote of the essence of technology at a time when the dominant types of technology were mechanical and industrial in form — what Ihde (2009, xii) describes as the "rust belt, smokestack industrial technologies" characteristic of the first half of the twentieth century - and not when electronic, digital, knowledge-based, and "technoscience" technologies were prevalent, as is the case now (Ihde 2010, 3). Although we live in an age dominated by a different form of technology, we argue that the new types of technology can still be conceived as having an essence or a mode of revealing that is enframing and that poses dangers for people, similar to the technology of Heidegger's time in his interpretation. Others agree with our position that Heidegger's account and critique of the essence of technology remain important and useful (e.g., Marcuse 1964; Thomson 2000, 2009; Polkinghorne 2004; Feenberg 2005; Kisiel 
2014). At the same time, we accept that not everyone agrees with Heidegger's account of the essence of modern technology and subsequently with our position.

\section{ENFRAMING IN HUMAN SERVICE PRACTICE}

Are the essence of modern technology (or enframing) and the dangers associated with it as described by Heidegger evident in practices of care? Human service practice is implicated in revealing being in particular ways, and often this is in the mode of enframing. According to Herbert Dreyfus $(1993,306)$, "Heidegger thinks the perfectly ordered society dedicated to the welfare of all is not the solution to our problems but the culmination of the technological understanding of being." In other words, the perfected welfare state where all resources, including human, have been efficiently mobilized, calculated, and ordered to provide material welfare for all is enframing par excellence (Dreyfus 1993). Many critiques of modern welfare emerge from and correspond with Heidegger's account of enframing. In particular, Heidegger's intellectual work on technology inspired (for want a better word) a radical left critique of welfare.$^{10}$ Moreover, Heidegger has been particularly influential on many theorists who critically assess modern welfare and human services; one who is most notable for our current purpose is Michel Foucault (Foucault 1977, 1988, 1997; Bernstein 1991; Irving 2009; Powell 2013).

Timothy Rayner (2001) provides an example of the relationship between Heidegger and Foucault's work, which hints at the way in which enframing pervades social welfare systems and practices. According to Rayner (2001, 142), "Heidegger and Foucault share the view that individuals in modern society are to some extent determined by technological structures pervading that society. Both develop the idea that the basic character of these structures is to objectify and order the forces of life. Both argue that the view of human beings as a kind of manipulable resource is essential to the technological management of society."

10. There is a body of left radical critique of welfare professional practice that points to the unwitting adoption or acceptance of neoliberal policy as well as the impact of new public management on welfare professional practice. See Foster and Wilding (2000), Fraser (2012), and Keating (2016). 
According to this point of view, practices of the caring professions can be an aspect or example of rationalities and technologies of modern government, or governmentality, that conceive of people as a resource or potential that can be efficiently normalized, constrained, and optimized with the right type of regulation, ordering, and discipline (Polkinghorne 2004; Miller and Rose 2008; Dean 2010). Dreyfus (2004) has also discussed the influences of Heidegger on Foucault's work. For example, Dreyfus (2004) suggests that Foucault's critique of objectification, normalization, governmentality, and bio-power follows Heidegger's critique of enframing and modern technology. In particular, Dreyfus (2004) argues, "Foucault, like Heidegger, is, of course, not opposed to modern welfare techniques . . . but he is opposed to taking for granted that welfare practices, based on the social sciences, should, in the name of efficiency and optimization, be extended without critical questioning to all aspects of our lives."

Søren Riis $(2009,127)$ also suggests that a consequence of enframing is the creation of "a manual for everything - including humans." The prevalence of guides, frameworks, tip sheets, and handbooks also indicates that the logic of enframing has captured human service practice. This discussion, though limited, suggests that according to much analysis, enframing offers a valuable heuristic for understanding and scrutinizing practices of care. And this is particularly the case when human beings are conceived and treated as human capital or human resources - things to be calculated and ordered, subjects to be disciplined, assets to be used, and populations to be optimized (Ihde 1979; Riis 2009; Thomson 2009; Emslie 2016). Similar to Heidegger, Foucault suggests that when practices of care are entangled with enframing, they limit human possibility while also emphasizing particular ways of understanding human beings. These reductions and amplifications are a problem and suppress and subjugate alternative ways of being.

We are not interested here in providing a comprehensive comparative analysis of Heidegger and Schön's accounts of modern technology and technical rationality. At the same time, one aspect of both of their respective arguments is relevant to our interest in human service practice. Even though Heidegger's (1977) detailed description of modern science and its essence is more sophisticated than Schön's account of positivistic science, both authors comment on the entanglement between their conceptualizations of science and technology in modern times. Heidegger (1977) argues that enframing, as the essence of modern technology, preceded modern 
science and that modern science emerged from enframing. According to Heidegger (1977, 21-23), even though "modern technology must employ exact physical science," the essence of modern technology is present in modern science and therefore modern technology occurred historically earlier. Heidegger's account of the relationship between modern physical science and the essence of technology is the invert of how this relationship is typically understood. According to the aforementioned definition from the online Oxford Dictionary (http://www.oxforddictionaries.com/definition /english/technology), technology is conceived of as "the application of scientific knowledge for practical problems," and this definition, which places science before technology, aligns with Schön's account of technical rationality. According to Heidegger and Schön, modern technology and technical rationality rely on science as an exact, calculable, and orderable way of knowing and form of knowledge. And professional practice that is based on modern technology or technical rationality is interdependent with modern, systematic, positivistic science and scientific knowledge. This being the case, the same arguments Schön presents to critique professional activity based on the model of technical rationality can be made to critique professional practice based on modern technology.

\section{THE SOLUTION ACCORDING TO HEIDEGGER-ART ORTECHNE}

According to Iain Thomson $(2009,157)$, “Heidegger insisted a real solution demands not that we abandon our technological manipulation and control of human beings (which he recognised will not happen in the foreseeable future), but rather that we find ways to integrate these technological projects for increasing self-optimization into our basic sense of self without allowing this sense of self to be completely dominated by enframing's optimization imperative." At the same time, Heidegger $(1977,26)$ makes the case that it is in the essence of technology that we are to find the alternative to enframing: "When we once open ourselves expressly to the essence of technology, we find ourselves unexpectedly taken into a freeing claim." Heidegger $(1977,29)$ argues that "in technology's essence roots and thrives the saving power" or "the promise" and that when we recognize and understand the "supreme danger" of the essence of modern technology, we experience "the lightning-flash of Being," or what Dreyfus $(1993,308)$ describes as a "sudden Gestalt switch," and a "transformation in our understand- 
ing of being" (Thomson 2009). ${ }^{11}$ Heidegger proposes that the alternative to enframing, which is simultaneously concealed by enframing, is a different mode of revealing that enables the real to appear to people in a different way.

In thinking about technology, Heidegger (1977) describes this other mode of revealing the real as "bringing-forth" and argues that this is the sort of revealing that was familiar to the Ancient Greeks, who called it poiesis. According to Heidegger $(1977,7)$, one thing that was particular to poiesis was its well-known four causes, which Heidegger argues were "the ways, all belonging at once to each other, of being responsible for something else."12 In other words, Heidegger (1977, 6-11) argues that the four causes, or the four ways of being responsible, or the four "modes of occasioning," are all at play within revealing as bringing forth or poiesis. Heidegger also makes the case that a crucial difference between the two modes of revealing - bringing forth and challenging forth - is to do with causality. In particular, Heidegger $(1977,23)$ argues that in modern times, "causality is shrinking into a reporting - a reporting challenged forth — of standing reserve." John Henry (2008) and Keekok Lee (2009) similarly observe that Galileo

11. It is reasonable to suggest that Heidegger's analysis of technology took place not in spite of, but rather as a result of, his initial support for and his later break with National Socialism (e.g., Dreyfus 1993). In light of this and Heidegger's claim that it is in the essence of technology that the saving power thrives, do we all need to engage with a political movement such as Nazism that is an extreme expression of faith in technological ordering and planned calculation to experience the "sudden Gestalt shift" or the lightening-flash of Being, and come to realize and appreciate the dangers of enframing and its alternative? Moreover, how this sudden Gestalt shift takes place deserves further attention (see Dreyfus 1993).

12. Aristotle proposes four kinds of causes or explanations when we ask the question "why?" According to traditional accounts of Aristotle's Physics and Metaphysics (e.g., Aristotle 1996, 38-42; 2004, 12-15), Aristotle says that when we explain change or movement in matter, it is determined by the material that composes the moving or changing things. Any change or movement of a table is a consequence of its being made of wood. Second, we can also explain any change or movement in form by its being caused by the arrangement, shape, or appearance of the thing changing or moving. Aristotle says, for example, that if we explain an octave in music, this is explained by the ratio $2: 1$, and number in general. Third, if we want to know why something has come into being, we look for an efficient or moving cause. For example, the efficient cause of a table is a carpenter. Finally, we can explain why something does what it does in terms of its end or purpose (telos). For a seed, for example, the purpose is to become an adult plant. Heidegger ([1976] 1998, 1977) offers what he claims to be a more originary interpretation of Aristotle's four causes and that complicates and challenges typical translations and interpretations. 
and others involved in the emergence of modern science were critical of the four causes and actively promoted a narrower approach to causation that emphasizes the material and efficient causes because they lent themselves to measurement and quantification.

Heidegger has more to say in his characterization of bringing forth or poiesis. In particular, he describes poiesis's relationship to the ancient Greek idea of technology. According to Heidegger (1977, 12-13), "The word [technology] stems from the Greek. Technikon means that which belongs to techne. We must observe two things with respect to the meaning of this word. One is that ... Techne belongs to bringing-forth, to poiesis.... The other point that we should observe with regard to techne ... [is that] it is as revealing ... that techne is a bringing-forth." In particular, Heidegger $(1977,13)$ argues that the ancient Greek techne is a revealing "according to the perspectives of the four modes of occasioning." Heidegger's account of the relationship between techne and poiesis aligns with Aristotle's and neo-Aristotelian accounts that suggest techne is the way of knowing most suited to guide poiesis as the form of activity (Dunne 1997, 2005; Flyvbjerg 2001; Polkinghorne 2004; Aristotle 2009).

Heidegger adds that in ancient Greece, art was called techne. Heidegger (1977, 34) argues: "Why did art bear the modest name techne? Because it was revealing that brought forth and hither, and therefore belonged within poiesis." Heidegger then suggests that the alternative to the mode of revealing that rules in modern technology (enframing) is to be found in the bringingforth that was revealed by art as the ancient Greeks knew it. Heidegger (1977, 35) argues: "Because the essence of technology is nothing technological, essential reflection upon technology and decisive confrontation with it must happen in a realm that is, on the one hand, akin to the essence of technology and, on the other, fundamentally different from it. Such a realm is art." Heidegger makes the case for a different essence or mode of revealing the real compared to the mode of enframing or challenging forth that dominates in modern technology. That different mode of revealing is a bringingforth mode of revealing, which is the type of revealing that ancient Greeks called techne, or art, and that has the four modes of occasioning at play. Because the four modes of occasioning are at play, art is not as reductionist and amplifying of the specific in its revealing the real compared to enframing.

Heidegger examines technology and does not directly investigate good professional practice like Schön does. At the same time, if enframing and 
the dangers associated with it are evident in human service practice, as we argue, then this suggests that practice should be based on a different way of revealing the real, and Heidegger proposes that this should be a mode called art. However, Heidegger argues that the way to the alternative to enframing is through enframing. In light of criticisms of enframing, we are unsure if human service practice should be based on this way of revealing the real. But if practice is not based on enframing, then, as Heidegger suggests, we will not experience the transformation in how the real is revealed. This circular argument is unresolvable and does not help us to think about and pursue an alternative to professional practice based on a technological fix. Moreover, Heidegger's failure to suggest some possibility for addressing enframing outside of enframing is an example of what Jürgen Habermas (1987) describes as a totalizing critique that leads to performative contradictions, a criticism Habermas leveled at Foucault.

Are there other ethical considerations in Heidegger's work that might help to define the point and purpose of a professional practice? Heidegger (1993) argues that he does not provide an explicit ethical theory in his account of Being. He begins by asking, "Can we obtain from such knowledge directives that can be readily applied to our active lives? The answer is that such thinking is neither theoretical nor practical. It comes to pass before this distinction. Such thinking is, insofar as it is, recollection of Being and nothing else. . . . Such thinking has no result. It has no effect" (1993, 259). On this basis, Jeremy Wisnewski $(2012,57)$ argues, "Heidegger . . . explicitly claims in several places in Being and Time that he is not interested in providing an evaluative analysis of the modes of Dasein's existence." According to Sacha Golob $(2015,1)$, "Essentially his [Heidegger's] view is that, before one can address ethics, construed as the question of how we ought to live, one needs to get clear on ontology, on the question of what we are." However, after getting clear on ontology, Heidegger does not return to this question. As John Paley $(2000,68)$ argues, all moral theories or ontic alternatives meet the ontological condition of Dasein, and "Heidegger makes absolutely no attempt to adjudicate between them."

Nonetheless we believe that Heidegger's work is hardly silent on the question of what is bad and good for people. Indeed, his account of the dangers of the essence of modern technology is an example of just that. In his 1951-52 lectures on thinking, he is clear that the nature of technology is not just a human fabrication that, given an appropriate moral constitution, could be subdued by superior human wisdom (Heidegger 1976). That said, any 
claims that Heidegger's work provides an obvious or unambiguous ethical theory are highly contested (e.g., van Buren 1992; Reich 1995; Philipse 1999; Paley 2000; Volpi 2007). Dreyfus $(1993,293)$ suggests that Heidegger would find such a theory to be an example of the problem of enframing, and Dreyfus argues that, according to Heidegger, true moral knowledge should not be explicit and disinterested like scientific knowledge. At the same time, we appreciate that professional practitioners need to make decisions and that these decisions should be good ones. If technology is not the panacea for good practice, and Schön and Heidegger's alternatives to technology are inadequate or too ambiguous, then is there an alternative?

\section{ANOTHER ALTERNATIVE TO ARTISTRY AND ART: PHRONESIS AND PRAXIS}

ARE HEIDEGGER'S AND SCHÖN'S SOLUTIONS ADEQUATE FOR GOOD PRACTICE?

Both Schön's and Heidegger's critiques of technical rationality and the essence of modern technology suggest we should not place too much confidence in making good practice in caring work reliant on technology. Schön directly critiques technology as both a tool and knowledge. Heidegger agrees that these negative assessments of technology are correct and then goes even further to criticize the essence of modern technology. However, are the alternatives to the technical rationality and enframing proposed by Schön and Heidegger adequate for good practice in human services? Moreover, is artistry including reflective practice (Schön) or art as the true essence of technology as a bringing forth or poiesis (Heidegger) the way to achieve good practice in social, youth, and community work? Many authors have critiqued Schön's work on reflective practice (e.g., Clandinin and Connelly 1986; Bleakley 1999; Newman 1999; Johns 2004) and Heidegger's account of the essence of modern technology, especially as it appears in The Question Concerning Technology (e.g., Feenberg 2002, 2005; Harman 2009; Riis 2009; Ihde 2010). These assessments suggest that Schön's and Heidegger's proposals are not what good practice in caring work requires, and we do not revisit these critiques here. Instead, we explore another possibility that is absent in Schön's and Heidegger's alternatives to technology and that is also typically missing from the examinations of these authors' work. This other alternative to technology, which is a gap in Schön's and Heidegger's 
work on technology, is Aristotle's intellectual virtue called phronesis and its corresponding form of action known as praxis.

Schön (1987) acknowledges that he did not explore wisdom per se. Schön (1987, xiii) writes, "I would like to say what I have not tried to do in this book. I have not considered how the teaching of applied science might best be combined with a reflective practicum. . . . I say little here about wisdom." At the same time, Schön (1987, xiii) argues, "I believe that education for reflective practice, though not a sufficient condition for wise or moral practice, is certainly a necessary one.” We agree that reflective practice can have a role to play in achieving good practice, but it is not enough on its own. Elizabeth A. Kinsella (2012) similarly suggests that this is a gap in Schön's work and proposes an elaboration of Schön's reflective practice in light of phronesis.

Heidegger's questioning reinvigorates a mode of revealing the real that the ancient Greeks called techne, or art, which Heidegger compares to the current mode of revealing, which he describes as enframing. Moreover, Heidegger focuses on the essence of technology and its ontological implications rather than on ethical or practical questions, such as how one should live or what one should do. Donald E. Polkinghorne $(2004,44)$ argues, "What is left out of Heidegger's analysis of technology is phronesis."13 Richard Bernstein $(1983 ; 1991,120)$ agrees that Heidegger passes over Aristotle's phronesis and praxis in The Question Concerning Technology and other work, and he makes the case that this "striking silence" by Heidegger is a significant gap. "The entire rhetorical construction of 'the Question Concerning Technology' seduces us into thinking that the only alternative to the threatening danger of Gestell [Enframing] is poiessis. It excludes and conceals the possible response of phronēsis and praxis" (Bernstein 1991, 122). Similarly, according to Polkinghorne $(2004,44)$, "Turning to Aristotle in 'The Ques-

13. Heidegger was deeply engaged with Aristotle prior to the publication of Being and Time (e.g., see Heidegger [1922/1923] 2007, [1924/1925] 2003, [1924] 2009, 1962). Many authors make the case that Aristotle's ethics and Aristotle's concept of phronesis are central to Heidegger's ontology (e.g., Sheehan 1975; Volpi 1992; Kisiel 1993; Coltman 1998; Weidenfeld 2011; Thanassas 2012). For example, according to Robert Bernasconi (1989), Heidegger has four equivalent ideas to Aristotle's phronesis - circumspection, understanding, resoluteness, and conscience. At the same time, Heidegger's interpretations and translations of Aristotle are both criticized and hotly debated (e.g., Bernasconi 1986; Gonzalez 1997, 2006; Brogan 1989, 2005; Taminiaux 2002; Kisiel and Sheehan 2007). However, Heidegger does not deploy phronesis as an alternative to the essence of modern technology. 
tion Concerning Technology' to introduce the Greek concept of techne as bring-forth . . . Heidegger omitted the other way of thinking, phronesis, which Aristotle describes in the same section [of Nichomachean Ethics].... Gadamer has proposed that phronesis enables us to respond to the dominance of contemporary technology in our lives." And Hans-Georg Gadamer (1975, 1979, [1960] 2004) is not the only person to argue just that. For example, other students of Heidegger's, in particular Hannah Arendt (1958), make a similar point. Moreover, many of Heidegger's students and many others who were subsequently influenced by Heidegger and his students specifically pursue phronesis and praxis - concepts that Heidegger introduced to many of his students in the 1920s - in ways contrary to how Heidegger appropriated these concepts in his own work. Lawrence J. Hatab (2000) also observes Heidegger's failure to consider praxis. Hatab $(2000,203)$ argues: "Another way to understand the shortcomings of Heidegger's political vision involves his preference for poiesis over praxis, for creative bring-forth over engaged social practice. . . For all his interest in Aristotle's ethics, Heidegger never followed through on Aristotle's praxis." Francisco J. Gonzalez (2006) helps explain this failure by making the case that Heidegger transforms and distorts Aristotle's meaning of praxis.

\section{PHRONESIS AND PRAXIS}

So what are phronesis and praxis? And how can phronesis and praxis help us to conceptualize and pursue good practice in the social services in ways that avoid the problems associated with technical rationality and enframing? To describe phronesis and praxis, it is useful to return to Aristotle, who was the first to characterize these ideas, in particular in his Nichomachean Ethics. Before we do that, it is important to note that Aristotle lived almost 2,400 years ago when life was very different, and some authors, most notably Foucault (1984) and Jürgen Habermas (1993), resist looking to the ancient Greeks for an ethical theory for contemporary times. ${ }^{14}$ On the other hand, many other authors, including Georg W. F. Hegel ([1807] 1977), Heidegger ([1924/1925] 2003), Alasdair MacIntyre (1984), Jacques Derrida

14. Habermas $(1973,1993)$ acknowledges Aristotle's distinctions between phronesis, techne, and episteme; however, he does not agree that phronesis is the best response to the problems posed by modern technology, technique, and a technical interest in the practical and political realms. 
(2001), Martha Nussbaum (2001), and Michael Sandel (2009), return to the ancient Greeks, and particularly to Aristotle, to help answer critical questions. We follow these authors' lead and believe that there is value in exploring the possibilities afforded by ancient ideas to assist with understanding and dealing with modern problems, and this includes the problem that we are addressing. Many other authors agree, and Richard Bernstein (1986), Shirley Grundy (1987), Joseph Dunne (1997, 2005), Jennifer White (2007, Stephen Kemmis and Tracey J. Smith (2008), Bill Green (2009), Elizabeth A. Kinsella and Allan Pitman (2012), Anna C. Petersén and Jan I. Olsson (2015), and Jon Ord (2016) are among those who suggest that phronesis and praxis offer possibilities for inspiring new kinds of professional practice that attempt to avoid the kinds of problems that our critique of technology identifies.

Aristotle (2009) discusses phronesis and praxis most significantly in Book VI of Nichomachean Ethics. The way in which Aristotle (2009) describes phronesis and praxis that is most relevant to our purposes is by relating and distinguishing these ideas from two other concepts that are also coupled-techne and poiesis. David Ross and Lesley Brown's (Aristotle 2009) translation and interpretation of Nichomachean Ethics, which is a traditional version of the text, translates phronesis as "practical wisdom," praxis as "acting," techne as "art," and poiesis as "making." To maintain consistency in our text, we continue to use the ancient Greek terms. ${ }^{15}$ One thing that phronesis and techne, as different intellectual virtues or types of knowledge, and praxis and poiesis, as different sorts of human activity, share is that they relate to variable things or matters that can be otherwise, rather than invariable things or unchanging objects (Aristotle 2009). If we accept that human services respond to variable things or matters that can be otherwise, rather than invariable things or unchanging objects, then we need to decide whether social services are better characterized or revealed as a praxis guided by phronesis, or as a poiesis guided by techne.

To help answer this question, we can look to Aristotle's descriptions of and distinctions between phronesis and praxis, and techne and poiesis.

15. According to Robert Bernasconi $(1986,111)$, Aristotle does not offer a sustained account of the distinction between praxis and poiesis because the distinction was already well known to Aristotle and his contemporaries. Bernasconi $(1986,111)$ adds, "Nor is there any clear agreement amongst scholars as to how the distinction is understood by him [i.e., Aristotle]." We do not follow these controversies and debates and closely follow Ross and Brown's interpretation and translation. 
Aristotle's (2009) accounts of techne and poiesis that resonate with descriptions of modern technology are among the most pertinent. In particular, Aristotle $(2009,105,106)$ argues, "All art [techne] is concerned with coming into being, i.e., with contriving and considering how something may come into being . . . and whose origin is in the maker and not in the thing made . . . [and] making [poiesis] has an end other than itself." Heidegger's ([1922/1923] 2003, 29) translation and interpretation of Aristotle's Nichomachean Ethics further illuminates the distinctive character of techne and poiesis. "The object of know-how [techne] is . . the finished product, which arises through a production and a fabrication [poiesis]. This [finished product] . . . is 'for the sake of something,' [Nichomachean Ethics $1139 \mathrm{bl}$ ], it has a relation to something else. . . The [finished product] . . is 'for something and for someone' [Nichomachean Ethics 1139b2]. . . . This double character entails that the [finished work] of the [production, poiesis] is for further use, for man [sic]." ${ }^{\prime 16}$ Similar to these descriptions of techne and poiesis, modern technology is concerned with making or producing things (typically for some other further use), begins with someone who is separate from the thing being made, and ends in something that is separate from the activity of making. We have already identified the problems with these ways of knowing and doing for practices in the social services in our critiques of the technical rationality offered by Schön and the criticisms of enframing provided by Heidegger. In light of these problems, human services should not be considered as poiesis guided by techne.

\section{PRAXIS AND PHRONESIS AND GOOD PRACTICE}

IN HUMAN SERVICES

This leaves revealing social services as a praxis guided by phronesis. So why are these better ideas for conceptualizing good practice in the human services? First, Aristotle $(2009,106)$ argues that, contrary to poiesis, praxis cannot have an end other than itself, "for good action [praxis] itself is its end." In other words, in his account of praxis, Aristotle offers a way to conceptualize action that avoids the kinds of problems that our critique of tech-

16. We suggest that what can be observed here in Heidegger's early translation and interpretation of Aristotle's account of techne in Nichomachean Ethics is an original glimpse of what was to become Heidegger's theory of enframing in The Question Concerning Technology. 
nology identifies. In particular, in the case of praxis, the end is not something separate to the action; the action is the end. But how is the action to be good action? This is where phronesis comes in. According to Aristotle $(2009,106)$, phronesis is a reasoned and true state of capacity to act with regard to human goods or to the things that are good or bad for human beings. In other words, phronesis is concerned with deliberation and good judgment regarding how human beings should be and, in particular, how they should act. Aristotle $(2009,109)$ adds that because action is concerned with particulars, phronesis recognizes and needs universal and particular knowledge, especially contingent, context-specific knowledge. This helps to explain why Aristotle (2009, xvi, 115-17) argues that there is a close connection between phronesis and moral virtue.

Second, phronesis is needed and exercised to determine what the virtuous act is in a particular circumstance-or phronesis is the intellectual reasoning that helps to guide the desire to pursue what is right and avoid what is wrong, as well as to make good choices regarding states of character or the moral virtues in a given instant (Aristotle 2009). Schwartz and Sharpe's (2010) account of phronesis captures these key ideas of the concept. "Ethics, said Aristotle . . . was about performing a particular social practice well - being a good friend or parent or doctor or soldier or citizen or statesman - and that meant figuring out the right way to do the right thing in a particular circumstance, with a particular person, at a particular time. This is what took practical wisdom [phronesis]" (Schwartz and Sharpe 2010, 5-6). Wisnewski (2012, 61-65) agrees that "The virtuous action [the action guided by phronesis or praxis] is one done in the right way, at the right time, to the right person, and with the right kind of knowledge" (see also Anscombe 1958; Bessant 2009; Eikeland 2014; Cheung 2016). According to Aristotle (2009), phronesis is the intellectual virtue best suited to guide praxis. And praxis, as a type of activity, is often understood as human action oriented toward some idea of the good that, while guided by universals, emerges in response to particulars or the context-specific contingencies of the given situation of practice itself (Polkinghorne 2004). Because the end of praxis is thought through and determined with the aid of phronesis in the specific context of action itself, rather than the end being a scientifically produced, predetermined rule or theory to be correctly applied in practice, and because the end of praxis is not separate from and for the sake of something outside the action itself, as it is in the case of poiesis guided by techne, praxis and phronesis offer a way to conceptualize good 
practice in the human services that could avoid the problems associated with technical rationality and enframing.

\section{THE ROLE OF TECHNOLOGY}

Where does this leave technology? More to the point, should technology still have a role in achieving good practice in human services? Some authors are suspicious of technology and suggest that techne and poiesis have no role to play in association with phronesis and praxis in professional practice (Arendt 1963; Carr 2004). This is because techne and poiesis are oriented toward making, manipulating, and controlling. For example, David Hamilton $(2005,40)$ argues: "Through techne one sees nature as something to be used and controlled. ... Both pre-modern and modern technologies regard nature as something to be used.” In other words, technology can be associated with the dangers of enframing no matter the era in which it is located. Other authors argue that technology still has a role to play and that pragmatically it is difficult to think about people and practice in modern times without technology (Thomson 2009). If technology has a role to play in achieving good practice in the caring professions, then what should it be? Most accounts that support technology having a role suggest that technology should be in the service of and subordinate to phronesis and praxis (Dunne 1997; Walker and Walker 2012; Carr 2014). This is a relationship to technology that Dreyfus (1993) suggests is supported by Heidegger's response to the technological understanding of being. This suggestion also makes sense in light of an assumption or claim that phronesis and praxis rest on: that each instance of practice is unique and practice is never the same thing twice. A relevant implication of this account of practice is that a critical aspect of exercising phronesis and doing praxis is that people have to decide in each instance of practice whether to use technology and, if so, what technology to use, when to use it, and why and how to use it.

\section{CONCLUSION}

We make the case that the idea of technology as a tool that includes new digital technologies has become fundamental to, and embedded in, ways in which good practice in the social services is conceptualized and pursued. We also argue that technology as knowledge, and in particular as a technicalrational conceptualization of knowledge, has been, and continues to be, ev- 
ident in professional practice and in particular in the assumption and expectation that good practice in practices of care are achieved with the correct application of theory produced by rigorous scientific research. We observe that this is evident in the current emphasis on evidence-based practice rooted in the social sciences.

Nevertheless, we argue that there are significant critiques of the relations between good human service practice and technologies. In particular, we examine the work of Schön and Heidegger and agree with these authors' suggestions that technical rationality and modern technology are not the way to achieve good practice in the human service professions. Furthermore, we acknowledge the ways in which Heidegger's account of the essence of modern technology problematizes conceptualizations and approaches to good practice that articulate or assume an efficacy, in particular because any claims or hopes of effectiveness, outcomes, or results can be revealed as examples of the problem of enframing people. We explore the alternatives to technical rationality and modern technology provided by Schön and Heidegger. We report that Schön advocates artistry or artful practice, which he suggests involves reflective practice. And we identify that Heidegger recommends a reinvigoration of art as conceived by the Ancient Greeks in the concept of techne.

However, we are not convinced that the proposals offered by Heidegger and Schön are what good practice in human services requires. At the same time, and in light of Heidegger's and Foucault's perspectives of social services, we acknowledge that accounts of good practice need to avoid reverting to a technical simplicity and efficacy. We take up this ambitious challenge and embark on a prefatory project of suggesting an alternative conceptualization of good social service practice. In particular, we explore another prospect that is absent in Schön and Heidegger's alternatives to technology and that is often missing from the critiques of these authors' work. We draw on Aristotle's account of the intellectual virtues to provide an alternative to techne and artistry. We introduce phronesis and praxis as other possibilities for inspiring new kinds of practice in the twenty-first century. We emphasize that phronesis and praxis are often characterized as different ways of knowing and doing compared to technical forms of knowledge and action, and we emphasize these distinctions.

Although they are both significant contributors, Heidegger and Schön are only two writers who have thought about technology and its implications. Other accounts are worthy of attention (e.g., Feenberg 2002, 2005; 
Latour 2002; Ihde and Selinger 2003; Olsen et al. 2009; Verbeek 2009; Ihde 2010). Attending to this body of work would go a long way toward further inquiries about what role, if any, technology could or should play in achieving good practice in human services. Further research is also needed on the question of the relationship between praxis, phronesis, and modern science and technology for good practice in the caring professions.

\section{NOTE}

Michael Emslie is a lecturer in youth work in the School of Global, Urban, and Social Studies at RMIT University in Melbourne, Australia.

Rob Watts is a professor in social science in the School of Global, Urban, and Social Studies at RMIT University in Melbourne, Australia.

\section{REFERENCES}

Anscombe, Gertrude Elizabeth. 1958. “Modern Moral Philosophy.” Philosophy 33 (124): 1-16. ARACY. n.d. "ARACY: Australian Research Alliance for Children and Youth: Collaboration, Evidence, Prevention.” Website. https://www.aracy.org.au/.

Arendt, Hanna. 1958. The Human Condition. Chicago: University of Chicago Press. . 1963. Eichmann in Jerusalem: A Report on the Banality of Evil. New York: Viking.

Aristotle. 1996. Physics, translated by Robin Waterfield and edited with an introduction and notes by David Bostock. Oxford: Oxford University Press.

. 2004. The Metaphysics, translated by and with an introduction by Hugh LawsonTancred. London: Penguin.

. 2009. The Nicomachean Ethics, rev. ed., edited by Lesley Brown and translated by W. D. Ross. Oxford: Oxford University Press.

Artemenko, Natalia. 2016. "The 'Ethical' Dimension of Heidegger's Philosophy: Consideration of Ethics in Its Original Source.” Russian Studies in Philosophy 54 (1): 62-75.

Australian Government Department of Human Services. 2015. "Service Delivery Transformation.” https://www.humanservices.gov.au/corporate/annual-reports/annual-report -2015-16/part-4-transforming-services-and-technology/service-delivery-transformation.

Barnatt, Christopher. 2001. “The Second Digital Revolution.” Journal of General Management 27 (2): 1-16.

Bernasconi, Robert. 1986. “The Fate of the Distinction between Praxis and Poiesis." Heidegger Studies 2:111-39.

. 1989. "Heidegger's Destruction of Phronesis." Southern Journal of Philosophy 28 (Suppl. 1): 127-47.

Bernstein, Richard. 1983. Beyond Objectivism and Relativism: Science, Hermeneutics and Praxis. Philadelphia: University of Pennsylvania Press.

- 1986. Philosophical Profiles: Essays in a Pragmatic Mode. Philadelphia: University of Pennsylvania Press. 
1991. The New Constellation: The Ethical-Political Horizons of Modernity/Postmodernity. Cambridge: Polity.

Berzin, Stephanie Cosner, Jonathon Singer, and Chitat Chan. 2015. "Practice Innovation through Technology in the Digital Age: A Grand Challenge for Social Work," Grand Challenges for Social Work Initiative Working Paper no. 12, American Academy of Social Work and Social Welfare, Cleveland, $\mathrm{OH}$.

Bessant, Judith. 2003. "The Science of Risk and the Epistemology of Human Service Practice.” Just Policy 31 (December): 31-38.

2004. "Risk Technologies and Youth Work Practice." Youth and Policy 83:60-76.

. 2009. "Aristotle Meets Youth Work: A Case for Virtue Ethics.” Journal of Youth Studies 12 (4): 423-38.

Bessant, Judith, Rys Farthing, and Rob Watts. 2017. The Precarious Generation: A Political Economy of Young People. London: Routledge.

Bleakley, Alan. 1999. "From Reflective Practice to Holistic Reflexivity." Studies in Higher Education 24 (3): 315-30.

Bondi, Liz, David Carr, Chris Clark, and Cecilia Clegg, eds. 2011. Towards Professional Wisdom: Practical Deliberation in the People Professions. Surrey: Ashgate.

Brogran, Walter. 1989. “A Response to Robert Bernasconi's "Heidegger's Destruction of Phronesis.” Southern Journal of Philosophy 28 (Suppl.): 149-53.

2005. Heidegger and Aristotle: The Twofoldness of Being. Albany, NY: SUNY Press.

Brooke, Heather. 2012. The Revolution Will Be Digitised: Dispatches from the Information War. London: Windmill Books.

Campbell Collaboration. n.d. "The Campbell Collaboration: What Helps? What Harms? Based in What Evidence?" http://www.campbellcollaboration.org/.

Carr, David. 2014. "Professionalism, Profession and Professional Conduct: Towards a Basic Logical and Ethical Geography." 5-27 in International Handbook of Research in Professional and Practice-Based Learning, edited by Stephen Billet, Christian Harteis, and Hans Gruber. Dordrecht: Springer.

Carr, Wilfred. 2004. "Philosophy and Education." Journal of Philosophy of Education 38 (1): $55-73$.

Chenoweth, Lesley, and Donna McAuliffe. 2012. The Road to Social Work and Human Service Practice. 3rd ed. South Melbourne: Cengage.

Cheung, Chun-Sing Johnson. 2016. "Practice Wisdom in Social Work: An Uncommon Sense in the Intersubjective Encounter.” European Journal of Social Work. doi: 10.1080/13691457 .2016.1255592.

Clandinin, Jean, and Michael Connelly. 1986. "Review Essay: The Reflective Practitioner and Practitioners' Narrative Unities.” Canadian Journal of Education 11 (2): 184-98.

Cochrane Collaboration. 2015. "Cochrane: Trusted Evidence. Informed Decisions. Better Health.” http://www.cochrane.org/.

Coltman, Rodney. 1998. The Language of Hermeneutics: Gadamer and Heidegger in Dialogue. Albany, NY: SUNY Press.

Corlett, Adam. 2016. "Robot Wars: Automation and the Labour Market." Resolution Foundation Briefing. http://www.resolutionfoundation.org/app/uploads/2016/07/Robot-wars .pdf. 
Cote, Marcel. 2010. "The Information Revolution" CA Magazine 143 (4): 48.

CSIRO. n.d. "Improving Digital Service Delivery." https://www.csiro.au/en/Research/D61 /Areas/Data-for-decisions/Digital-service-delivery.

Dean, Mitchell. 2010. Governmentality: Power and Rule in Modern Society. 2nd ed. London: Sage.

Derrida, Jacques. 2001. Writing and Difference, translated by Alan Bass. Abingdon, Oxon: Routledge.

Dreyfus, Herbert. 1993. "Heidegger on the Connection between Nihilism, Art, Technology and Politics." 289-316 in The Cambridge Companion to Heidegger, edited by Charles B. Guignon. Cambridge: Cambridge University Press.

2004. "Being and Power: Heidegger and Foucault." Unpublished manuscript, University of California, Berkeley. http://socrates.berkeley.edu/ hdreyfus/html/paper_being.html.

Dunne, Joseph. 1997. Back to the Rough Ground: Practical Judgment and the Lure of Technique. Notre Dame, IN: University of Notre Dame.

. 2005. "An Intricate Fabric: Understanding the Rationality of Practice." Pedagogy, Culture and Society 13 (3): 367-89.

du Sautoy, Marcus. 2016. What We Cannot Know: Explorations at the End of Knowledge. London: Fourth Estate.

Early Intervention Foundation. n.d. "Right for Children, Better for the Economy." http:// www.eif.org.uk/.

eheadspace. 2015. "eheadspace Can Help." https://www.eheadspace.org.au/.

Eikeland, Olav. 2014. "Phronesis." 623-27 in The Sage Encyclopedia of Action Research, edited by David Coghlan and Mary Brydon-Miller. London: Sage.

Eisner, Elliot. 2002. "From Episteme to Phronesis to Artistry in the Study and Improvement of Teaching." Teaching and Teacher Education 18:375-85.

Emslie, Michael. 2016. "The Entanglement of the Stuff and Practice of Human Service Work: A Case for Complexity." Social Work and Social Sciences Review 18 (2): 25-42.

Esping-Andersen, Gosta. 1990. The Three Worlds of Welfare Capitalism. Princeton, NJ: Princeton University Press.

Feenberg, Andrew. 2002. Transforming Technology: A Critical Theory Revisited. New York: Oxford University Press.

2005. Heidegger and Marcuse: The Catastrophe and Redemption of History. New York: Routledge.

Flyvbjerg, Bent. 2001. Making Social Science Matter. Cambridge: Cambridge University Press.

Foster, Peggy, and Paul Wilding 2000. "Whither Welfare Professionalism?" Social Policy Administration. 34 (2): 143-59.

Foucault, Michel. 1977. Discipline and Punish: The Birth of the Prison. Ringwood: Penguin. . 1984. "On the Genealogy of Ethics: An Overview of Work in Progress." 340-72 in The Foucault Reader: An Introduction to Foucault's Thought, edited by Paul Rabinow. London: Penguin.

. 1988. "Technologies of the Self." 16-49 in Technologies of the Self: A Seminar with Michel Foucault, edited by Luther Martin, Huck Gutman, and Patrick Hutton. Amherst: University of Massachusetts Press. 
1997. Ethics, Subjectivity and Truth: The Essential Work of Michel Foucault, 19541984, vol. 1, edited by Paul Rabinow. New York: New Press.

Fraser, Nancy. 2012. "Feminism, Capitalism, and the Cunning of History: An Introduction." FMSHWP-2012-17. < halshs-00725055>.

Furedi, Frank. 2011. "Introduction to the Marketisation of Higher Education and the Student as Consumer." 1-7 in The Marketisation of Higher Education and the Student as Consumer, edited by Mike Molesworth, Richard Scullian, and Elizabeth Nixon. Abingdon: Routledge.

Gadamer, Hans-Georg. (1960) 2004. Truth and Method. Revised 2nd ed., translated by Joel Weinsheimer and Donald G. Marshall London: Bloomsbury.

1975. "Hermeneutics and Social Science." Cultural Hermeneutics 2:313-14.

1979. "The Problem of Historical Consciousness." 103-62 in Interpretive Social Science: A Reader, edited by Paul Rabinow and William Sullivan. Berkeley: University of California Press.

Gambrill, Eileen. 2013. Social Work Practice: A Critical Thinker's Guide. 3rd ed. New York: Oxford University Press.

Golob, Sacha. 2015. "Martin Heidegger: Freedom, Ethics, Ontology." Forthcoming in The Cambridge History of Moral Philosophy, edited by Sacha Golob and Jens Timmermann. Cambridge: Cambridge University Press.

Gonzalez, Francisco J. 1997. “On the Way to Sophia: Heidegger on Plato's Dialectic, Ethics, and Sophist." Research in Phenomenology 27:16-60.

. 2006. "Beyond or Beneath Good and Evil? Heidegger's Purification of Aristotle's Ethics." 127-56 in Heidegger and the Greeks, edited by Drew Hyland and John Panteleimon Manoussakis. Bloomington: Indiana University Press.

Green, Bill, ed. 2009. Understanding and Researching Professional Practice. Rotterdam: Sense. Grundy, Shirley. 1987. Curriculum: Product or Praxis. East Sussex: Falmer.

Habermas, Jürgen. 1973. Theory and Practice, translated by John Viertel. Boston: Beacon. - 1987. The Philosophical Discourse of Modernity, translated by Frederick G. Lawrence. Cambridge, MA: MIT Press.

1993. Justifications and Applications: Remarks on Discourse Ethics, translated by Ciaran Cronin. Cambridge, MA: MIT Press.

Hamilton, David. 2005. "Knowing Practice." Pedagogy, Culture and Society 13 (3): 285-89.

Harman, Graham. 2009. "The McLuhans and Metaphysics." 100-22 in New Waves in the Philosophy of Technology, edited by Berg Olsen, Jan Kyrre, Evan Selinger, and Søren Riis. Basingstoke, Hampshire: Palgrave Macmillan.

Hatab, Lawrence J. 2000. Ethics and Finitude: Heideggerian Contributions to Moral Philosophy. Lanham, MD: Rowman \& Littlefield.

Hegel, Georg W. F. (1807) 1977. The Phenomenology of Spirit, translated by A. V. Miller, with analysis of the text and foreward by J. N. Findlay and an introductory note by J. N. Mohanty. New York: Oxford University Press.

Martin Heidegger. (1922/1923) 2007. "Phenomenological Interpretations with Respect to Aristotle: Indication of the Hermeneutical Situation." 155-84 in Becoming Heidegger: On the Trail of His Early Occasional Writings, 1910-1927, edited and translated by Theodore Kisiel and Thomas Sheehan. Evanston, IL: Northwestern University Press. 
. (1924) 2009. Basic Concepts of Aristotelian Philosophy, translated by Robert D. Metcalf and Mark Basil Tanzer. Bloomington: Indiana University Press.

_. (1924/1925) 2003. Plato's Sophist, translated by Richard Rojcewicz and Andre Schuwer. Bloomington: Indiana University Press.

. 1962. Being and Time, translated by John Macquarrie and Edward Robinson. New York: Harper \& Row.

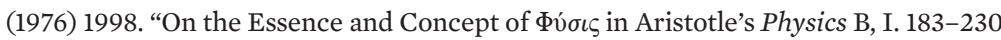

in Martin Heidegger: Pathmarks, edited by William McNeill and translated by Thomas Sheehan. New York: Cambridge University Press.

. 1976. What Is Called Thinking? translated by Jesse Glenn Gray and Fred Dernburg

Wieck. New York: Harper Perennial.

- 1977. The Question Concerning Technology and Other Essays, translated by William Lovitt. New York: HarperCollins.

—. 1993. "Letter on Humanism." 213-66 in Martin Heidegger: Basic Writings, rev. and expanded ed., edited by David Farrell Krell. London: Routledge.

Heinsch, Melina, Mel Gray, and Elaine Sharland. 2016. "Re-conceptualising the Link between Research and Practice in Social Work: A Literature Review on Knowledge Utilisation." International Journal of Social Welfare 25 (1): 98-104.

Henry, John. 2008. The Scientific Revolution and the Origins of Modern Science. 3rd ed. Basingstoke, Hampshire: Palgrave Macmillan.

Holton, Gerald. 1988. Thematic Origins of Scientific Thought: Kepler to Einstein. Cambridge, MA: Harvard University Press.

Ihde, Don. 1979. Technics and Praxis. Boston: Reidel.

—. 2009. "Foreward." viii-xiii in New Waves in Philosophy of Technology, edited by Berg Olsen, Jan Kyrre, Evan Selinger, and Søren Riis. Basingstoke, Hampshire: Palgrave Macmillan.

. 2010. Heidegger's Technologies: Postphenomenological Perspectives. New York: Fordham University Press.

Ihde, Don, and Evan Selinger, eds. 2003. Chasing Technoscience: Matrix for Materiality. Bloomington: Indiana University Press.

Irving, Allan. 2009. "Michel Foucault." 43-52 in Social Work Theories and Methods, edited by Mel Gray and Stephen Webb. London: Sage.

Johns, Chris. 2004. Becoming a Reflective Practitioner. 2nd ed. Oxford: Blackwell.

Keating, Frank. 2016. "Social Welfare Policy in Racialized Contexts." 110-22 in Policy and Social Work Practice, edited by Tony Evans and Frank Keating. London: Sage.

Kemmis, Stephen, and Tracey Smith, eds. 2008. Enabling Praxis: Challenges for Education. Rotterdam: Sense.

Kincaid, Susan, ed. 2004. Technology in Human Services: Using Technology to Improve Quality of Life. Chicago: Council for Standards in Human Service Education.

Kinsella, Elizabeth A. 2012. "Practitioner Reflection and Judgement as Phronesis: A Continuum of Reflection and Considerations of Phronetic Judgment." 35-52 in Kinsella and Pitman 2012, 35-52.

Kinsella, Elizabeth A., and Allan Pitman, eds. 2012. Phronesis as Professional Knowledge: Practical Wisdom in the Professions. Rotterdam: Sense. 
Kisiel, Theodore. 1993. The Genesis of Heidegger's “Being and Time.” Berkeley: University of California Press.

. 2014. "Heidegger and Our Twenty-First Century Experience of Ge-Stell." 137-51 in The Multidimensionality of Hermeneutic Phenomenology, edited by Babette Babich and Dimitri Ginev. Dordrecht: Springer.

Kisiel, Theodore, and Thomas Sheehan. 2007. Becoming Heidegger: On the Trail of His Early Occasional Writings, 1910-1927. Evanston, IL: Northwestern University Press.

Kuhn, Thomas. 2012. The Structure of Scientific Revolutions. 4th ed. Chicago: University of Chicago Press.

Latour, Bruno. 2002. "Morality and Technology: The End of the Means," edited by Couze Venn. Theory, Culture and Society 19 (5-6): 247-60.

Lee, Keekok. 2009. "Homo Faber: The Unity of the History and Philosophy of Technology." 13-39 in New Waves in the Philosophy of Technology, edited by Berg Olsen, Jan Kyrre, Evan Selinger, and Søren Riis. Basingstoke, Hampshire: Palgrave Macmillan.

Livingstone, Rob. 2015. "How to Guard Your Career against Rapid Technological Change." The Conversation, June 11. http://theconversation.com/how-to-guard-your-career-against -rapid-technological-change-42304.

MacIntyre, Alasdair. 1984. After Virtue: A Study in Moral Theory. 2nd ed. London: Duckworth. Malpas, Jeff. 2014. "The Twofold Character of Truth: Heidegger, Davidson, Tugendhat.” 24366 in The Multidimensionality of Hermeneutic Phenomenology, edited by Babette Babich and Dimitri Ginev. Dordrecht: Springer.

Marcuse, Herbert. 1964. One-Dimensional Man: Studies in the Ideology of Advanced Industrial Society. Boston: Beacon.

Martin, Jennifer, and Linette Hawkins, eds. 2010. Information Communication Technologies for Human Service Education and Delivery: Concepts and Cases. Hershey, PA: Information Science Reference.

Matthewman, Steve. 2011. Technology and Social Theory. London: Palgrave Macmillan.

McQuivey, James. 2013. Digital Disruption: Unleashing the Next Wave of Innovation. Las Vegas, NV: Forrester.

Michie, Susan, Maartje van Stralen, and Robert West. 2011. "The Behaviour Change Wheel: A New Method for Characterising and Designing Behaviour Change Interventions." Implementation Science 6 (42): 1-11.

Miller, Peter, and Nikolas Rose. 2008. Governing the Present: Administering Economic, Social and Personal Life. Cambridge: Polity.

Newman, Stephen. 1999. "Constructing and Critiquing Reflective Practice." Educational Action Research 7 (1): 145-63.

Nicholson, Graeme. 2014a. "On the Manifold Meaning of Truth in Aristotle." 227-42 in The Multidimensionality of Hermeneutic Phenomenology, edited by Babette Babich and Dimitri Ginev. Dordrecht: Springer.

- 2014b. "Truth and Unconcealedness." Gatherings: The Heidegger Circle Annual 4: $70-85$.

Nussbaum, Martha C. 2001. The Fragility of Goodness: Luck and Ethics in Greek Tragedy and Philosophy. Revised ed. Cambridge: Cambridge University Press. 
Olsen, Berg, Jan Kyrre, Evan Selinger, and Søren Riis, eds. 2009. New Waves in the Philosophy of Technology. Basingstoke, Hampshire: Palgrave Macmillan.

Ord, Jon. 2016. "The Importance of Aristotle's Phronesis in Resisting Instrumentality in Youth Work in England." 105-18 in The History of Youth Work in Europe: Autonomy through Dependency: Histories of Co-operation, Conflict and Innovation in Youth Work, vol. 5, edited by Lasse Siuala, Filip Coussée, Leena Suurpää, and Howard Williamson. Strasbourg: Council of Europe.

Osmond, Jennifer, and Ian O'Connor. 2006. "Use of Theory and Research in Social Work Practice: Implications for Knowledge-Based Practice.” Australian Social Work 59 (1): 5-19. Paley, John. 2000. "Heidegger and the Ethics of Care.” Nursing Philosophy 1:64-75.

Perron, Brian, Harry Taylor, Joseph Glass, and Jon Margerum-Leys. 2010. "Information and Communication Technologies in Social Work.” Advanced Social Work 11 (2): 67-81.

Petersén, Anna, C., and Jan I. Olsson. 2015. "Calling Evidence-Based Practice into Question: Acknowledging Phronetic Knowledge in Social Work.” British Journal of Social Work 45:1581-97.

Philipse, Herman. 1999. "Heidegger and Ethics.” Inquiry 42:439-74.

Polkinghorne, Donald. 2004. Practice and the Human Sciences: The Case for a JudgmentBased Practice of Care. Albany, NY: SUNY Press.

Popper, Karl. 1979. Objective Knowledge: An Evolutionary Approach. Rev. ed. Oxford: Oxford University Press.

Powell, Jason. 2013. "Michel Foucault." 46-62 in Social Work Theories and Methods, 2nd ed., edited by Mel Gray and Stephen Webb. London: Sage.

Power, Michael. 1997. The Audit Society: Rituals of Verification. Oxford: Oxford University Press.

Rayner, Timothy. 2001. "Biopower and Technology: Foucault and Heidegger's Way of Thinking." Contretempts 2:142-56.

ReachOut.com. n.d. "About Us." http://about.au.reachout.com/?utm_campaign=supporters \&utm $\_$source $=$reachout\&utm_medium $=$topnav.

Reamer, Frederic. 1993. The Philosophical Foundations of Social Work. New York: Columbia University Press.

- 2012. "The Digital and Electronic Revolution in Social Work: Rethinking the Meaning of Ethical Practice." Ethics and Social Welfare 7 (1): 2-19.

_. 2013. "Social Work in a Digital Age: Ethical and Risk Management Challenges." Social Work 58 (2): 163-72.

_. 2015. "Clinical Social Work in a Digital Environment: Ethical and Risk-Management Challenges." Clinical Social Work Journal 43:120-32.

Reich, Warren. 1995. "History of the Notion of Care." 319-31 in Encyclopedia of Bioethics, edited by Warren Reich. 5 vols. New York: Simon \& Schuster Macmillan.

Riis, Søren. 2009. "The Question Concerning Thinking." 123-45 in New Waves in the Philosophy of Technology, edited by Berg Olsen, Jan Kyrre, Evan Selinger, and Søren Riis. Basingstoke, Hampshire: Palgrave Macmillan.

Safranski, Rudiger. 1998. Martin Heidegger: Between Good and Evil. Cambridge, MA: Harvard University Press.

Sandel, Michael. 2009. Justice: What's the Right Thing to Do? London: Penguin. 
Schön, Donald. 1983. The Reflective Practitioner: How Professionals Think in Action. Aldershot: Ashgate.

1987. Educating the Reflective Practitioner: Toward a New Design for Teaching and Learning in the Professions. San Francisco: Wiley.

Schwandt, Thomas. 2005. "On Modelling Our Understanding of the Practice Fields." Pedagogy, Culture and Society 13 (3): 313-32.

Schwartz, Barry, and Ken Sharpe. 2010. Practical Wisdom: The Right Way to Do the Right Thing. New York: Penguin.

Selwyn, Neil. 2014. Distrusting Educational Technology. Abingdon: Routledge.

Sheehan, Thomas. 1975. "Heidegger, Aristotle and Phenomenology." Philosophy Today, Summer, 87-94.

. 2011. "Astonishing! Things Make Sense!” Gatherings: The Heidegger Circle Annual $1: 1-25$.

Slavin, Simon, and Richard Schoech. 1999. Human Services Technology: Understanding, Designing, and Implementing Computer and Internet Applications in the Social Services. 2nd ed. Binghamton, NY: Haworth.

Susskind, Richard, and David Susskind. 2015. The Future of the Professions. Oxford: Oxford University Press.

Suvák, Vladislav. 2000. "The Essence of Truth (Aletheia) and the Western Tradition in the Thought of Heidegger and Patocka." Thinking Fundamentals, IWM Junior Visiting Fellows Conferences, vol. 9, Vienna.

Taminiaux, Jacques. 2002. "The Interpretation of Aristotle's Notion of Areté in Heidegger's First Courses." 13-27 in Heidegger and Practical Philosophy, edited by François Raffoul and David Pettigrew. Albany, NY: SUNY Press.

Thanassas, Panagiotis. 2012. "Phronesis versus Sophia: On Heidegger's Ambivalent Aristotelianism." Review of Metaphysics 66 (1): 31-59.

Thompson, Neil. 2000. Theory and Practice in Human Services. Buckingham: Open University Press.

Thomson, Iain. 2000. "From the Question Concerning Technology to the Quest for a Democratic Technology: Heidegger, Marcuse, Feenberg." Inquiry 43:203-16.

- 2009. "Understanding Technology Ontotheologically, or The Danger and the Promise of Heidegger, an American Perspective." 146-66 in New Waves in the Philosophy of Technology, edited by Berg Olsen, Jan Kyrre, Evan Selinger, and Søren Riis. Basingstoke, Hampshire: Palgrave Macmillan.

van Buren, John. 1992. "The Young Heidegger, Aristotle, Ethics." 169-85 in Ethics and Danger: Essays on Heidegger and Continental Thought, edited by Arleen Dallery, Charles Scott, and P. Holley Roberts. Albany, NY: SUNY Press.

Verbeek, Peter-Paul. 2009. "Cultivating Humanity: Towards a Non-Humanist Ethics of Technology." 241-63 in New Waves in the Philosophy of Technology, edited by Berg Olsen, Jan Kyrre, Evan Selinger, and Søren Riis. Basingstoke, Hampshire: Palgrave Macmillan.

Volpi, Franco. 1992. "Dasein as Praxis: the Heideggerian Assimilation and the Radicalization of the Practical Philosophy of Aristotle." 90-129 in Martin Heidegger: Critical Assessments, edited by Christopher Macann. New York: Routledge. 
. 2007. "In Whose Name? Heidegger and 'Practical Philosophy," translated by Niall Keane. European Journal of Political Theory 6 (1): 31-51.

Walker, Joyce, and Kate Walker. 2012. "Establishing Expertise in an Emerging Field." 39-51 in Advancing Youth Work: Current Trends, Critical Questions, edited by Dana Fusco. New York: Routledge.

Watling, Sue, and Jim Rogers. 2012. Social Work in a Digital Society. London: Sage.

Webb, David. 2011. Heidegger, Ethics and the Practice of Ontology. New York: Continuum.

Weidenfeld, Matthew. 2011. "Heidegger's Appropriation of Aristotle: Phronesis, Conscience, and Seeing through the One." European Journal of Political Theory 10 (2): 254-76.

White, Jennifer. 2007. "Knowing, Doing and Being in Context: A Praxis-Oriented Approach to Child and Youth Care." Child and Youth Care Forum 36:225-44.

Wisnewski, Jeremy. 2012. "Heidegger's Aristotelian Ethics." 57-77 in Ethics and Phenomenology, edited by Mark Sanders and Jeremy Wisnewski. Lanham, MD: Lexington Books.

Wolin, Sheldon. 1993. The Heidegger Controversy: A Critical Reader. Cambridge, MA: MIT Press.

Young and Well Cooperative Research Centre. 2013. "Young and Well Cooperative. Research Centre." http://www.youngandwellcrc.org.au/. 